Copyrights by University of Chicago Press: Britt, B. (1998). "Snapshots of Tradition: Apparitions of the Virgin Mary in Georgia." Nova Religio: The Journal of Alternative and Emergent Religions 2 (1): $108-125$.

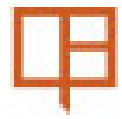

UNIVERSITY OF CALIFORNIA PRESS

JOURNALS + DIGITAL PUBLISHING

Snapshots of Tradition: Apparitions of the Virgin Mary in Georgia

Author(s): Brian Britt

Source: Nova Religio: The Journal of Alternative and Emergent Religions, Vol. 2, No. 1

(October 1998), pp. 108-125

Published by: University of California Press

Stable URL: http://www.jstor.org/stable/10.1525/nr.1998.2.1.108

Accessed: 07/02/2014 12:13

Your use of the JSTOR archive indicates your acceptance of the Terms \& Conditions of Use, available at

http://www.jstor.org/page/info/about/policies/terms.jsp

JSTOR is a not-for-profit service that helps scholars, researchers, and students discover, use, and build upon a wide range of content in a trusted digital archive. We use information technology and tools to increase productivity and facilitate new forms of scholarship. For more information about JSTOR, please contact support@jstor.org.

University of California Press is collaborating with JSTOR to digitize, preserve and extend access to Nova Religio: The Journal of Alternative and Emergent Religions. 


\title{
Snapshots of Tradition: Apparitions of the Virgin Mary in Georgia
}

\author{
Brian Britt
}

\begin{abstract}
On the thirteenth of each month, from October 1990 until May 1994, Nancy Fowler appeared on the porch of a farmhouse in Conyers, Georgia, to deliver the message she had received from an apparition of the Virgin Mary. On apparition days, up to 80,000 people brought rosaries and cameras to the grounds of the farm. This essay analyzes the use of traditional religious discourse and modern technologies such as photography by participants in the Conyers gatherings. Participants have also employed electronic mail and electromagnetic wave measurements to verify and legitimate the monthly apparitions. My analysis suggests that Conyers brings together traditional Marian discourse and modern technology to create a dynamic and popular religious setting.
\end{abstract}

$\mathrm{N}$ ancy Fowler is a married Roman Catholic who moved to Georgia in 1988, when she began seeing visions of Jesus. ${ }^{1}$ Regular visions of Mary began in 1990, and in 1991, after the crowds had outgrown Fowler's property, Virginia businessman Robert Hughes purchased land near her house and formed an organization called Our Loving Mother's Children. The organization distributes books and flyers on the phenomenon and maintains an active Internet discussion group. ${ }^{2}$ Monthly apparitions continued until May 13, 1994, when Fowler, in part due to pressure from local civic and church officials, announced that they would take place only once a year, in October. Nevertheless, "Fowler still receives a teaching message from Jesus on the 13th of each month, and Mary gives a Message for the United States on October 13 of every year."

Many groups visited Conyers on apparition day: reporters and camera people, people in wheelchairs, and thousands of others in church tour groups, with families, or alone. While some viewed the gathering as a spectacular miracle, others treated it as an opportunity to bring specific petitions or to practice quiet devotions. Many people took Polaroid photographs of the area around the farmhouse, but far more-a clear majority—participated in the Rosary recitation. I suggest 
that two factors account for the popularity and robustness of the Conyers apparitions: (1) the familiar and traditional discourse of Marian apparitions, and (2) the novel use of cameras and other technologies to legitimate the apparitions. The cameras, which are used to capture miraculous images of glowing objects, rays of light, or Mary herself, reinforce various forms of belief, practice, and spectacle.

\section{TRADITIONAL MARIAN DISCOURSE}

Modern Marian apparitions have their roots in twelfth- and thirteenth-century legends associated with Marian shrines in such places as Chartres, Soissons, and Laon. ${ }^{4}$ By the fifteenth century, reports of public and serial apparitions of Mary were widespread in Spain and other parts of Europe..$^{5}$ According to William Christian, Jr., Marian apparitions declined from the sixteenth until the nineteenth century due in part to the Inquisition. ${ }^{6}$ In the mid-eighteenth century, Pope Benedict XIV endorsed the limited use of apparitions and related phenomena for religious instruction, and this support increased in the nineteenth century, especially under Pope Pius IX:

By "crowning" Marian shrine images, the papacy associated them with the universal church. Rome also endorsed a new series of proclamations of Marian images as patrons of dioceses or provinces. And it regarded with increasing sympathy visions of Mary that led to the establishment of new shrines. ${ }^{7}$

The modern period of Marian apparitions began in France, especially at LaSalette (1846) and Lourdes (1858), both of which enjoy official papal recognition and continued popularity today. ${ }^{8}$ Along with new papal support, the modern apparitions drew strength from what David Blackbourn calls the feminization of nineteenth-century Catholicism, a development in which women and femininity became more prominent in popular religion. ${ }^{9}$ As a form of piety in Catholicism, participation in Marian pilgrimages continues to grow worldwide. ${ }^{10}$ According to a Vatican-sponsored Internet publication, there are over 300 Marian apparition sites in the world today. ${ }^{11}$ Current pilgrimage and apparition sites include Fatima (Portugal), Garabandal (Spain), Betania (Venezuala), Medjugorje (Bosnia-Herzegovina), Knock (Ireland), Bayside/Flushing Meadows (New York), and Emmitsburg (Maryland). Building on the revival of Marian piety and apparitions, Mariology has joined angelology and other New Age phenomena as part of the wider popular religious culture. Public interest in the subject has produced books ranging from Franz Werfel's The Song of Bernadette to Ron Hansen's Mariette in Ecstasy; films such as Therèse; and television and newspaper coverage of Marian apparitions. ${ }^{12}$ 
Nova Religio

Since the fifteenth century, Marian apparitions have shared a number of general characteristics that apply also to Conyers: the visions gain a public following and occur serially; they represent Mary as an intercessor for her followers in some crisis; they express divine anger at particular sins (e.g., irreverence and atheism); and they are accompanied by a message of warning as well as miraculous signs, especially healings. ${ }^{13}$ At Conyers, such traditional signs as spinning suns and the changing colors of rosary beads are joined by such innovations as miraculous brain waves and atmospheric radiation-which require more advanced technological devices to measure and test. The use of miraculous Polaroid photographs as further testimony first became widespread at Bayside, New York (19701975), where Veronica Leuken, a housewife like Nancy Fowler, drew thousands of followers. ${ }^{14}$

In the modern period, at Fatima, Portugal (1917), and Garabandal, Spain (1961), apparitions of the Virgin have communicated warnings that have often been apocalyptic in nature. ${ }^{15}$ According to Sandra Zimdars-Swartz, a "transcultural, apocalyptic ideology based on apparition messages" has arisen in twentieth-century Catholic culture. ${ }^{16}$ The messages at Conyers, which, in the tradition of Fatima, took place on the thirteenth of the month, share this apocalyptic ideology. In 1991, for instance, Fowler reported the following statement by Mary: "Tensions within countries are mounting. Unless you turn back to God this nation will be in a great war." ${ }^{17}$ According to the messages, returning to God involves devotion to Jesus, Mary, and the Catholic sacraments, and a rejection of such practices as abortion.

Nancy Fowler belongs to a long history of women mystics whose power derives from Marian apparitions; like many women since the thirteenth and fourteenth centuries, Fowler often experiences her visions during Mass. ${ }^{18}$ These visions share the rich detail of their medieval counterparts, in which images are carefully described and then interpreted allegorically. ${ }^{19}$ The content of her apparitions follows the conventions of Christian visionary discourse:

Later Nancy said, "Rays of light are streaming from the Mother of God's hand and streaming to my left and now to my right. The rays of light are graces. The rays of light are penetrating into your hearts. Thank you for your petitions. Not a single one do I miss. All will be carried to the Throne of God." ${ }^{20}$

As Christian notes of the fifteenth century, apparitions have long followed established literary conventions: "Apparitions borrowed from legends, and over time they became legends." ${ }^{21}$

Anthropological studies of Marian apparitions concentrate on structural descriptions of ritual and sacred space, but John Eade and Michael Sallnow suggest that apparitions can also offer a "textual pilgrimage." ${ }^{22}$ Traditional discourse and texts give apparitions their 
structure and context, regardless of whether the pilgrim visits a physical space or "cyberspace." With their clear dependence on traditional visionary discourse, an e-mail listserve, and extensive publications, Fowler's apparitions constitute a textual pilgrimage. By referring directly to previous Christian visionaries and by inscribing her visions on paper before reading them, Fowler makes the written text a primary means of communication and a focus of her message. The e-mail listserve creates a disembodied cyberspace in which these messages appear, in seemingly random rotation, over the Internet. Listserve members also exchange messages, most often in the form of requested prayers and petitions. When she appears before the crowd reading her transcribed vision, Fowler models the spiritual behavior of lectio divina.

If Conyers belongs to a tradition of religious discourse and pilgrimage, then what social function does it serve? Anthropologists are divided between the idea of pilgrimage (1) as the reinforcement of social roles and structures (following Durkheim) and (2) as an antistructural, universalistic phenomenon promoting communitas. ${ }^{23}$ But since participants are diverse, it is not immediately clear that Conyers fits only one of these models. Conyers provides a setting in which to practice a popular kind of Catholic piety-pilgrimage to a Marian devotional site-which may suggest the social reinforcement model. ${ }^{24}$ The messages and structure of the Conyers phenomena are conventional and unoriginal, except for a certain folksy style in Fowler's delivery:

While driving in her car, Nancy said, "I really like this cruise control because it allows me to set it so it drives the car and I can pray my Rosary."

Jesus then said, "If only My children would see My gifts that way."

Fowler's admonitions to maintain the sacramental life and to obey Church authorities also suggest the social reinforcement model. On the other hand, former Atlanta Archbishop Lyke's warning about Fowler may indicate a concern not only about authenticity but also about an anti-hierarchical communitas: "Priests are not to accept invitations to lead pilgrimages or visits to Conyers, nor are they to initiate such. . . It is important that we not create the perception or impression that I or the Archdiocese endorse or authenticate these alleged apparitions." ${ }^{26}$

To build on the metaphor of textual pilgrimage, we can consider Conyers, and even individual participants, as a "realm of competing discourses." 27 For some people at certain times, Conyers represents communitas, while for others, it reinforces traditional norms of Catholic piety and teaching. The sheer numbers and diversity of participants at Conyers would make a single perspective on its meaning incomplete. 
Nova Religio

Written accounts of Conyers take several forms. In Wake Up America! Take My Heart, Take My Hand, Ann Marie Hancock celebrates the Conyers apparitions as truthful, inspirational events. ${ }^{28}$ Enthusiastically confessional in tone, the book includes interviews with Fowler, testimony from clergy, reports of miraculous healings, and "scientific studies" that claim to affirm the authenticity of the apparitions. Taken as a whole, Hancock's book endorses Nancy Fowler's apparitions on two grounds: faith and fact.

One can also read about Conyers in the newspapers and follow television coverage of the events, which depicts both the site and the activities surrounding Nancy Fowler. Each month, especially when the weather permitted good attendance, area news media crowded an area near the farmhouse designated for cameras, crews, and their vans. Journalists have focused on testimony about miracles as well as on Fowler's personality and such key players as the Archbishop of Atlanta. But journalistic accounts leaves out the apparitions' cultural context and history and remains relatively silent about such conceptual issues as belief. The conflicting depictions of Conyers as a devotional site for believers and a media spectacle create the need for first-hand observation. ${ }^{29}$

Descriptions of the location and actions surrounding this phenomenon, as well as conversations with participants, are indispensable to understanding it. The considerable body of literature produced and distributed by organizers of the gatherings conveys a partial and highly conventional version of these gatherings at Fowler's farmhouse. But readers of this literature might never discover that 20,000 to 80,000 people visited Conyers each month to recite the Rosary, climb the Holy Hill, and take Polaroid snapshots of the farmhouse and the sky during apparitions. After hearing reports about the apparitions from the media and from students, I decided to visit the farm on a scheduled apparition day. As it turns out, this ethnographic experiment had negative lessons-it taught me that what really happens there is complex and relatively unspectacular. In the spirit of Karen McCarthy Brown's Mama Lola, which breaks down the distinction between insider and outsider, the following narrative is impressionistic and includes my own reactions. ${ }^{30}$

\section{NARRATIVE: MAY 13, 1994}

Participants assemble and begin reciting the Rosary at about noon. About an hour later, from inside the "Apparition Room" of the farmhouse, a soft-spoken man reports what Fowler sees and hears over a loudspeaker. The apparition gives the ordinary Rosary devotion an extraordinary dimension. ${ }^{31}$ The people of the crowd are not simply 
witnesses to the miracle; they contribute to it. It seems to work like efficacious grace in reverse, from the grassroots up, with a self-described "plain Jane" as focus. It occurs to me that this populism and female authority may be what trouble the Atlanta archbishop.

When the apparition concludes, the man's voice announces that the Virgin Mary's image is ascending to the ceiling, and immediately hundreds or perhaps thousands of cameras begin clicking. This is the high point of the day, when devout participants become more typically American spectators. Some audience members clutch stacks of snapshots from previous occasions. One family has framed a Polaroid in which they see telltale gleams of miraculous light. A man sits in a lawn chair with his young son watching the print develop. "Didn't get much this time," he says. But a woman nearby tells me she saw the image of Our Lady going up the chimney with her arms extended.

Nancy Fowler appears on her front porch at about two o'clock wearing a pale green blouse and a long brownish skirt. Her graying hair blows in the breeze as she addresses the crowd. After every clause, a man translates simultaneously into Spanish. About seven priests and lay people (men and women) stand in a row behind her. There is something superfluous about the reading of the message, because it repeats word for word the account of the apparition given by the man who is now translating into Spanish. It serves as a kind of ritualized recitation of the "spontaneous" event that has just happened.

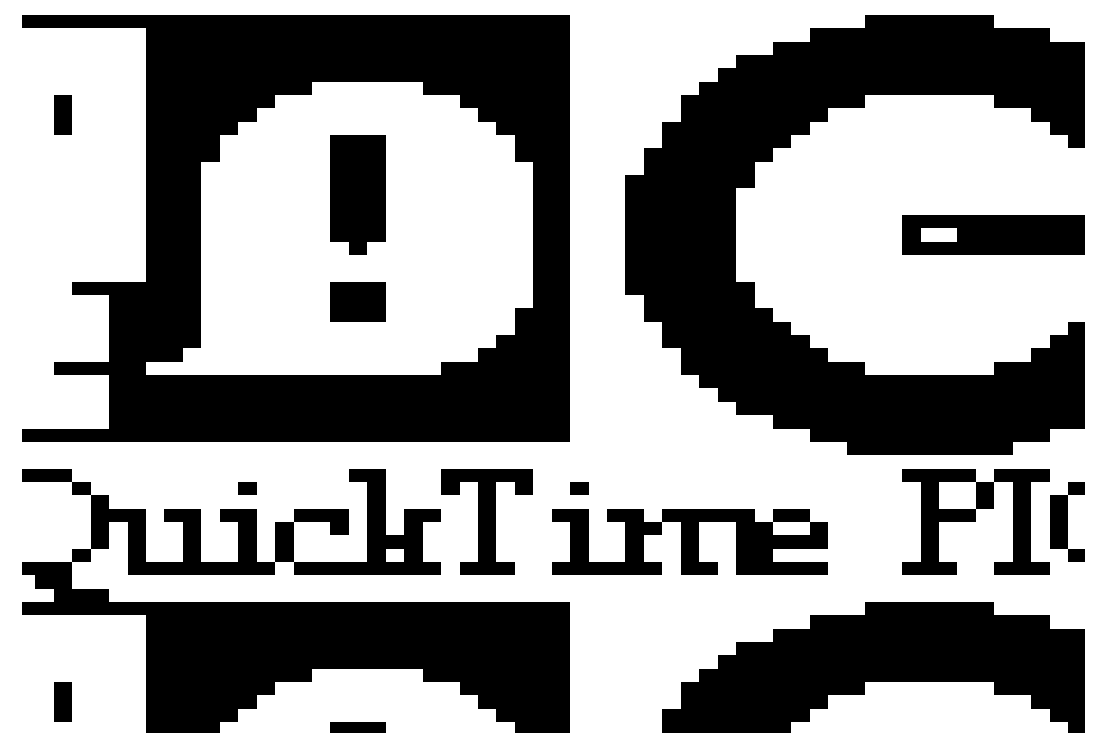

The visionary, Nancy Fowler (center, holding microphone), announcing Mary's message from the porch of the Apparition Room. (Photo courtesy of Victor Balaban) 
Nova Religio

Not much in the message is novel: repent, say the Rosary, give everything to Jesus, go to the sacrament of confession, pray. At one point she loses her place in the text; the man holding her clipboard finds it again. The only mention of current events is the "strife" in the former Yugoslavia and Africa. "Look at our cities," she says. "How can we say that we're one nation under God if we live with laws that are a mockery of God?"

The most surprising announcement comes later in the address, when Fowler reports that the Virgin has decided she will not appear any more on a monthly basis. Fowler's delivery is more impromptu at this point and sounds almost sheepish. She will appear again, she says, but only in times of "great need and trial." There are other, approved apparition sites, such as Fatima, she says, implying that her followers might consider taking their spiritual business elsewhere.

Today about 40,000 people from all over the country have come to see Nancy Fowler. About a hundred buses are parked close together in the area near the house. There is also a sizable area for handicapped parking. The closest vehicles are the eight trucks and vans from the news media. Local Atlanta television stations and one Spanish-speaking station share a premium viewing area with a dozen or so other reporters near the front of the house. Cameras and microphones are trained on the porch. There isn't this much press presence every month, but today there is a story about a family and friends praying for the safe return of a young student who has disappeared.

Fowler concludes by discussing the visual details of today's and other recent visions. In patterns and iconography that have been formulaic since the thirteenth-century Eucharistic visionaries, Fowler describes seeing the crucifix glowing and a host around the face of Jesus, along with "many many saints." She interprets this vision as meaning that Jesus is living bread and eternal light. At Mass this morning she saw the host burst into light when it was elevated. In another vision, Mary descended on a great pillar, followed by two blood red columns. Fowler notes that the vision is very much like a dream of nineteenth-century visionary St. John Bosco. The columns are red because of the persecution of the Eucharist. "But you know what? The immaculate heart will reign when it stands on top of that column!" [Applause.]

\section{TRADITION, RITUAL, AND TECHNOLOGY}

Simple observation of the gatherings at Conyers cannot determine the motives, experiences, or beliefs of participants. Some preliminary observations are, however, warranted. First, while participants are numerous and diverse, the gatherings provide a coherent and recognizable setting that draws from the traditional discourse of Marian 
apparitions and Catholic piety (e.g., Rosary recitation, Eucharistic visions, injunctions to partake of the sacraments, references to visionaries like St. John Bosco, and apocalyptic messages). Second, the fact that Fowler's visions are announced ahead of time and that recitation of the Rosary precedes them further ritualizes the event and connects participants directly to the miracles. By creating a ritualized space, devotees help bring about the apparitions: "As the Prayer Group began the first Sorrowful Mystery [of the Rosary], The Agony in the Garden, Nancy said Our Loving Mother's face became sad." ${ }_{2}$ Third, the widespread use of cameras at Conyers suggests that this technology serves not only to record what takes place but also to provide a new instrument of religious expression and testimony.

At Conyers, the poles of spectacle and devotion seem interdependent. The media and some participants view Fowler as spectacle, but thousands of others, without cameras and apparently absorbed in quiet prayer, appear less interested in miracles than devotion. Still, the miracles are the ostensible reason for the gathering. The notion that such beliefs should die away in a more "rationalized" and technologically advanced age has faded significantly from scholarship on religion, as have many other negative assumptions about premodern religions. Throughout the study of religion and increasingly in the popular media, reports on the robustness of all kinds of religion have become commonplace.

It is also no longer a shock to point out the multiplicity of human beliefs. Current thought on human nature-in cognitive science, philosophy, literary theory, and cultural studies-has developed sophisticated ways to talk about the apparent contradiction between believing one can photograph the Virgin Mary and demanding rigorous empirical tests in assessing other phenomena (e.g., cars, taxes, and the law). Mary Douglas writes, "We moderns operate in many different fields of symbolic action ... we do not bring forward from one context to the next the same set of ever more powerful symbols: our experience is fragmented. Our rituals create a lot of little sub-worlds, unrelated." 33

But what is especially interesting in Conyers is the paradoxical use of cameras not so much as tests but as vehicles of belief and ritual participation. More than any other modern household object, the camera has become the premier tool of empirical proof; the camera does not lie. At Conyers, cameras may perform several functions: for some they would always confirm authenticity, for others they would always disprove it, and for still others they would affirm authenticity only under certain conditions. Beliefs in the authenticity of supernatural or miraculous events could be sketched on a continuum from complete acceptance to total dismissal. ${ }^{34}$ While some need very little evidence to support such beliefs, others, like Jean-Paul Sartre, seem unwilling to accept any evidence for supernatural reality: 

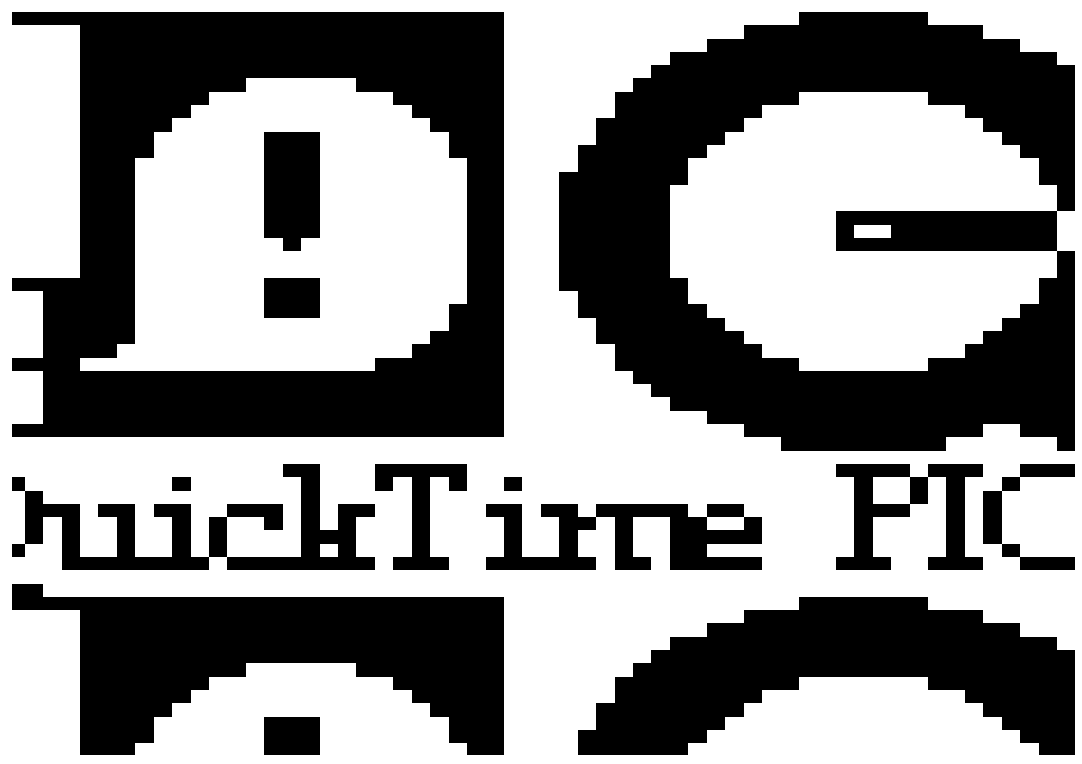

Miraculous photographs at Conyers, Georgia: One of the folk devotions that is emerging among Marian pilgrims is taking photographs of the sun and looking for signs of Jesus or Mary in the shapes that result. Marian symbolism has traditionally been associated with the sun, based partially on the Book of Revelation, whose figure of "the woman clothed with the sun" is believed to represent Mary. (Photo courtesy of Victor Balaban)

If an angel comes to me, what proof is there that it's an angel? And if I hear voices, what proof is there that they come from heaven and not from hell, or from the subconscious, or a pathological condition? What proves that they are addressed to me? What proof is there that I have been appointed to impose my choice and my conception of man on humanity? I'll never find any proof or sign to convince me of that. ${ }^{35}$

Cameras thus support a range of beliefs and enable some to change their beliefs. Beliefs may be hidden or latent, waiting to be brought out by the stimulus of a Polaroid.

"To photograph," writes Susan Sontag, "is to appropriate the thing photographed. It means putting oneself into a certain relation to the world that feels like knowledge-and, therefore, like power." ${ }^{\text {" F }}$ For the thousands of photographers at Conyers who ritualistically capture evidence or potential evidence of the apparitions on film, Sontag's point is relevant. Just as the communal recitation of the Rosary before and during the apparitions suggests an effective role for participants, so with the cameras, to photograph is even to constitute the thing photographed. ${ }^{37}$ 
The Conyers photographers appropriate and constitute reality by appropriating a technology that defines reality as imitation. Jean Baudrillard attributes the proliferation of Polaroids and video to a culture of "frantic self-referentiality" in which the simulacrum replaces the original:

This is the special effect of our times. The ecstasy of the polaroid is of the same order: to hold the object and its image almost simultaneously as if the conception of light of ancient physics or metaphysics, in which each object was thought to secrete doubles or negatives of itself that we pick up with our eyes, has become a reality. It is a dream. It is the optical materialization of a magical process. The polaroid photo is a sort of ecstatic membrane that has come away from the real object. $^{38}$

At Conyers, the camera is not an instrument of "objectivity" but rather a perception-heightening ritual object.

Victor Balaban, author of an essay on Fowler, posted a question on the Conyers listserve as to whether the photographs taken there are miraculous. He then summarized:

I thought that people might be interested to know that the responses I got (about 7 or 8 ) were all of the opinion that the photographs taken at Conyers are not miraculous. I don't know if that is representative of the views of everyone on the list, but I thought people might be curious to know. ${ }^{39}$

Balaban's notice generated the following response from listserve member Matias Serani:

The pictures that are taken in Conyers, GA are only to be seen with the eyes of Our FAITH. Anything else is just a waste of time on our behalf, so for that reason dear friends I suggest you do not dwell on the details obtained in these pictures, but focus on what Our Most Holy Mother is trying to communicate to us. ${ }^{40}$

Serani's statement affirms the apparition's authenticity. But by emphasizing faith and minimizing the photos, he tacitly acknowledges other belief perspectives. The head of the listserve, Jim Drzymala, later issued a statement asking listserve members to "refrain from posting anything to this list that is not related to the Conyers apparitions." 4 For these two listserve devotees, the discussion of miraculous photographs seems to arouse discomfort.

Like the camera, the computer serves to reinforce various types of belief and practice among participants at Conyers. The Conyers e-mail listserve is an electronic mailing list that had about 400 subscribers in $1995 .{ }^{42}$ At an average of about one message a day, the listserve circulates the text of Fowler's apparitions. There are also occasional petitions and 
offers to send petitions for sick or troubled individuals. By sending messages that are often unsigned, the listserve creates a timeless, decontextualized effect. The date of a posting may bear no relation to the date of the reported event. Timelessness may also be inherent in some types of message, for instance, messages concerning mystical union. The following message, entitled "December 29, 1994 Part 4," was posted on March 21, 1995:

"Oh dearest daughter, I love you. Now don't you feel like you are in Heaven? [Nancy later said that at that moment she felt the real presence of Jesus and the Blessed Mother like she experienced when Jesus took her to Heaven.] When you pray and really give Me your heart, then you have a special union with Me. Union with Me is Heaven. If you want more moments of Heaven, then have more moments of union with me."

Nancy said, "I think I am understanding that Heaven is a place and a state of your soul."

"Now you can teach My theologians some things. Tell all of them, I desire they have a bigger heart and less intelligence."

George said, "Maybe they [the Church] should have people with bigger hearts and less brains being the theologians."

Jesus replied through Nancy, "Let them figure it out. They are smart. You know that I had fun with My scribes and My pharisees. They thought they had the answers and I showed that they did not."

Nancy said Jesus was smiling.

Through the complexity of e-mail technology, messages like these take on a heightened authority and simplicity; Jesus speaks through Mary against the theologians, but only in this timeless, visionary cyberspace. ${ }^{43}$ Subscribers may download files at any time, and they post new messages on miracles, special intentions, or upcoming trips to Guadalupe, Lourdes, or Medjugorje, without setting them in any particular time or place. The listserve operates with remarkable smoothness, as if the technology is a transparent and obvious vehicle for expression. (The admonition from Drzymala to restrict postings to Conyers-related phenomena, mentioned above, is an exception.) While it follows traditional Marian discourse, this textual pilgrimage is not linear, but highly adaptable and personalized. Like the camera, the computer becomes a tool for appropriating and expressing religious experience.

There have also been attempts to confirm the miracles by measuring energy waves at Conyers and on Fowler herself. Extensive documentation of testing done by at least seven scientists and physicians in 1993 appears in a book and video called Why Do You Test Me? ${ }^{44}$ The battery of tests included a psychological exam, EEG brain wave measurements, and 
atmospheric testing in the Apparition Room and at the farm. Before the tests began, Fowler reported a vision in which Jesus said, "Watch what I will do." ${ }^{45}$ In every case, the scientific testing reported that Fowler was physically and mentally healthy but that her brain waves and the atmosphere registered extraordinary readings. Atlanta neurologist Ramon M. Sanchez even found numerological significance in the EEG data: "Satan is appearing to Nancy during this time and you can see this 6 hertz occurring and reoccurring, so you are getting this pattern of 666. Is this wild or something? And with Christ it is 333." ${ }^{46}$

Test results also appear in a chapter of Hancock's book called "The Scientific Studies." According to Hancock, the author of the following report, Dr. Philip Callahan, "is internationally recognized for his studies involving extensive artistic and infrared analysis of the Image of The Virgin Mary in the basilica of Guadalupe" and of the Shroud of Turin: ${ }^{47}$

I spent the morning up to 10:30 measuring the Atmospheric Schumann frequencies on the cross hill near the apparition room. The ELF Schumann atmospheric frequencies, 1-70 Hz, were extremely high in the area. This is generally true of all apparition sites I have measured e.g., Knock, Kerrytown Ireland, Lourdes, and La Salette, France and Medugorji [sic]. The VLF atmospheric frequencies from $100 \mathrm{~Hz}$ to $400 \mathrm{~Hz}$ were also very strong as is usual in apparition area.... Astonishly [ sic] the oscilloscope showed that within 20 to 30 seconds Nancy went into the $8 \mathrm{~Hz}$ meditative state. . . Even more astonishly [ $s i c]$ she soon started generating what are known as group or bullseye waves (waves that go out in ripples from the center like throwing a rock in water). It would take a textbook of mathematics to explain the physics of such waves. I have never received such energy from any living creature before (plants or animals) with my detector and oscilloscope..$^{48}$

The oscilloscope, which measures unseen forces, joins the camera in legitimating the miraculous nature of the apparitions. The quantity and quality of these waves, which only a "textbook of mathematics" could explain, nevertheless defy scientific explanation. The reality that appears ordinary without scientific instruments becomes astonishing. While the ostensible purpose of these studies is to authenticate the apparitions, they also provide new modes for traditional religious expression: the brain waves and atmospheric radiation indicate the miraculous but conventional figures of Mary, Satan, and Jesus.

Other reported miracles include smells and visions of roses, rosaries turning gold, and medical healings. For many miracles, efforts have been made to authenticate the events empirically. On April 13, 1996, a friend of Fowler, George Collins, addressed the pilgrims gathered at Conyers in Fowler's place, partly to announce that Fowler would no longer make regular public appearances. During his remarks, which appeared on the Conyers listserve, he spoke about miracles: 
God has given us many signs here. The sun spins and many people are able to see it. We don't encourage you to look at it but many people report the sun is spinning. Others smell roses. Many, many people have smelled the roses. The gold dust. There are numerous signs but they are signs to help us increase our faith. That is the important thing. ${ }^{49}$

While increasing faith may be the true purpose of the signs, Collins's need to say so suggests a variety of beliefs and practices among participants, including those who seek healing and cling to Polaroids. When one listserve member asked whether rose petals really fall from the sky at Conyers, another replied,

When I was in Conyers in May 1994, fresh petals of Ylang-Ylang, a fragrant flower from the Philippines fell. . . I I was praying by the Statue of Virgin Mary that was surrounded by pine trees. My mom, wife, sister and everybody at that location saw it. I even kept some of the petals and put them in a bottle of oil I bought from Padre Pio's church in Pennsylvania. ${ }^{50}$

Another writer reports running computerized metallurgical tests on a rosary that "turned gold":

We tested the rosary ... showed no signs of gold, just the original components. BUT $>$ a very close observation under a microscope revealed the exact same colors as my gold wedding ring. So $>$ conclusion, Yes they turn golden color. Sometimes even before your eyes. The result $>$ Veronica Garcia calls them candy kisses from Heaven. ${ }^{51}$
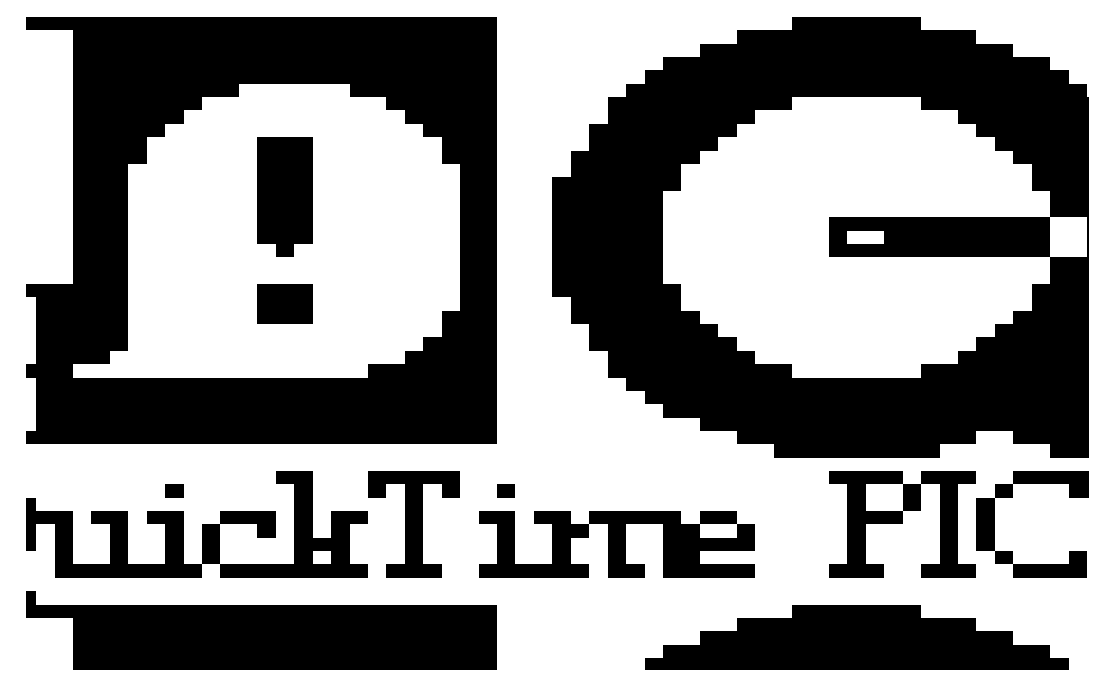

These "miraculous photographs" are taken home by pilgrims and become holy objects in their own right. (Photo courtesy of Victor Balaban) 
Even scientific tests with negative results can intensify belief in the Conyers miracles, because these tests represent new songs in the traditional key of Marian discourse.

\section{CONCLUSION}

Conyers is a setting where the traditional discourse of Marian apparitions gains added legitimacy through technological means. For thousands of people, the reported miracles and messages from the Virgin Mary follow a pattern familiar at many apparition sites around the world. The conventions of women visionaries and Marian apparitionsEucharistic visions, allegorically-interpreted images, apocalypticism, ritualized Mariology, and miraculous phenomena such as healings and spinning suns-constitute a kind of canonical text for participants to read and interpret. ${ }^{52}$

Marian devotion is centuries-old, but Fowler belongs to the modern wave of apparitions that dates back to the nineteenth century. Like LaSalette and Lourdes, Conyers represents a "feminized" and popular form of piety. But unlike her nineteenth-century counterparts, Fowler and her supporters recruit technology for this traditional (and some say anti-modern) purpose. If Fowler's apparitions, by their appeal to miracles and tradition, resist contemporary social values, they do so with state-ofthe-art technology. ${ }^{53}$

Adherents exploit a variety of technologies, including cameras, oscilloscopes, and a computer listserve, to affirm the authenticity of the apparitions. Far from transforming or challenging the tradition of apparitions, these technologies have been fully assimilated into this tradition by the devout participants. Conyers thus illustrates the remarkable robustness — even revival—of Marian apparitions in the face of contemporary scientific and social values. What cultural and religious factors can explain this revival?

Marian apparitions continue to thrive in part because they accommodate many interdependent groups-traditionalist Catholics seeking a return to pre-Vatican II devotions and certainties, HispanicAmerican Catholics, seekers of healing, doubters, and the religiously curious, to name only a few. The apparitions are able to draw widespread public attention because the mass media has discovered their appeal. Accounts of Marian apparitions are as likely to appear on the evening news as on such popular programs as Strange Universe or The Unexplained. Marian devotion may also fulfill a number of religious and psychological needs not met by male images of God and a patriarchal church structure.$^{54}$ Finally, apparitions continue to succeed because they are allowed to do so. Even though the Archdiocese of Atlanta has kept Fowler at arm's length, the Church strongly encourages Marian devotion and pilgrimage to approved apparition sites. 
Nova Religio

ENDNOTES

${ }^{1}$ Victor Balaban, "The Marian Apparition Site at Conyers, Georgia," in Religions of Atlanta (Atlanta: Scholars Press, 1996), 220-21. See also his photoessay of the same title in Religious Studies News (November 1996): 9 ff. I wish to thank Jessica Meltsner, Darleen Pryds, and Matthew Martin for helpful comments on drafts of this essay, an earlier version of which I presented to the Southeastern Committee for the Study of Religion in March, 1995. John Rakestraw helped me to clarify my thinking on the concept of belief. Gary Laderman allowed me to read a draft of Balaban's essay. Donna Arauz went to Conyers before me and gathered important information. Phillip Lucas and an anonymous reader for Nova Religio provided insightful and helpful suggestions. I especially wish to thank Nichole Arnault for many hours of research on this project.

${ }^{2}$ See http://www.conyers.org

${ }^{3}$ Balaban, "The Marian Apparition Site in Conyers, Georgia," 216.

${ }^{4}$ William A. Christian, Jr., Apparitions in Late Medieval and Renaissance Spain (Princeton: Princeton University Press, 1981), 5. Three of the main scholarly works on Marian apparitions are Sandra Zimdars-Swartz, Encountering Mary (Princeton: Princeton University Press, 1991); David Blackbourn, Marpingen: Apparitions of the Virgin Mary in a NineteenthCentury German Village (New York: Vintage Books, 1993); and Victor and Edith Turner, Image and Pilgrimage in Christian Culture (New York: Columbia University Press, 1978).

${ }^{5}$ Christian, Apparitions, 8.

${ }^{6}$ Ibid., 3,8 .

${ }^{7}$ William Christian, Jr., Visionaries (Berkeley: University of California Press, 1996), 2-3; Blackbourn, Marpingen, 36; and Zimdars-Swartz, Encountering Mary, 9.

${ }^{8}$ Zimdars-Swartz, Encountering Mary, 11.

${ }^{9}$ Blackbourn, Marpingen, 30-31.

${ }^{10}$ Turner and Turner, Image and Pilgrimage, 38. For a history of Mariology, see Jaroslav Pelikan, Mary Through the Centuries (New Haven: Yale University Press, 1996).

${ }^{11}$ Albert A. Caprio, O. P., "The Apparitions of the Virgin Mary," 1, available on the World Wide Web at: http://info.rutgers.edu/catholic-center/publish/FrAICaprio/ Apparitions.html.

${ }^{12}$ See also Michael P. Carroll, The Cult of the Virgin Mary: Psychological Origins (Princeton: Princeton University Press, 1986); Pelikan, Mary; and Joan Ashton, Mother of All Nations (New York: Harper and Row, 1989).

${ }^{13}$ Christian, Apparitions, 82-84, 146-7. See also Zimdars-Swartz, Encountering Mary, 247-50, and Turner and Turner, Image and Pilgrimage, 209-10.

${ }^{14}$ Ingo Swann, The Great Apparitions of Mary (New York: Crossroad, 1996), 211-15.

${ }^{15}$ An influential figure in this area is Catholic thinker St. Louis-Marie de Montfort (16731716). My thanks to Steve Perry for pointing this out to me.

${ }^{16}$ Zimdars-Swartz, Encountering Mary, 247. Apocalyptic themes are also prominent in the nineteenth century. See Blackbourn, Marpingen, 33-34.

17 "To Bear Witness that I AM the LIVING SON of GOD," vol. 2, compiled by Our Loving Mother's Children (Newington, VA: 1992), 75.

${ }^{18}$ See, for example, Hadewijch of Brabant, "Visions," in Elizabeth Petroff, ed., Medieval Women's Visionary Literature (New York: Oxford University Press), 195. See also Caroline Walker Bynum, Fragmentation and Redemption (New York: Zone Books, 1992), 122 ff.

${ }^{19}$ Petroff, Women's Visionary Literature, 31. See, for example, the eucharistic context and visual detail of the vision from January 12, 1993:

"Before the Mass Nancy saw a very bright, white light over the crucifix. During the Mass at 
the Gospel, Nancy saw a separate, all white image of a man standing behind the podium. At the Consecration of the Mass, Nancy saw the chalice burst into a great white light and the light remained over the chalice for a long time. Shortly afterwards Nancy saw a giant size, all black image of a beast-like man appear. This man was snatching away the chalice ... J Jesus then said, 'The evil one does not want people to drink of the cup of salvation. He wants to take the cup of life away from them'" (Conyers listserve message, LISTSERV@UBVM.CC.BUFFALO.EDU, posted February 16, 1995).

20 "To Bear Witness that I AM the LIVING SON of GOD, "vol. 2, 47. As part of the tradition of women visionaries, the Fowler apparitions become part of a debate on whether, by providing divine messages without the sacramental help of male priests, they challenge or subvert the patriarchal structure of the Church. Or is Fowler's gift, together with her obedience to the Church, the exception that proves the rule, a kind of special case of female insight that only reinforces women's usual distance from authority? There is certainly nothing subversive about Conyers, unless thousands of people praying peacefully at a farm under a lay woman's leadership is subversive. In Fragmentation and Redemption, Bynum argues that this question and the related debate on communitas depends on whether one takes men's or women's point of view: "If one looks with women rather than at women, women's lives are not liminal to women-but neither, except in a very partial way, are male roles or male experiences" (Bynum, 48).

${ }^{21}$ Christian, Apparitions, 208.

${ }^{22}$ John Eade and Michael J. Sallnow, eds., Contesting the Sacred (London: Routledge, 1991), 3-4.

${ }^{23}$ See Turner and Turner, Image and Pilgrimage, 37, and Eade and Sallnow, Contesting the Sacred, 3-4. See also the discussion of Italian carnivals in Lucia Chiavola Birnbaum, Black Madonnas (Boston: Northeastern University Press, 1993), 90-92. Turner and Turner list four main kinds of Christian pilgrimage: prototypical, syncretistic, medieval, and modern/ personal. Of course, pilgrimage to Conyers most closely fits the last category, though it shares characteristics of each. Medieval pilgrimage was highly conventionalized, and Conyers shares some of these conventions: people travel in groups (often by chartered bus); they observe ritual behaviors in different areas of the farm, such as a Holy Hill, a well, and a path with the Stations of the Cross; and some also visit local restaurants in the spirit of the bumper sticker that says, "Eat, Drink and See Mary."

${ }^{24}$ The space set aside at Conyers for people with illness and disabilities reflects another convention of Marian pilgrimage:

"Interviews with sick pilgrims at Lourdes during the summer of 1984 revealed that 'healthy' pilgrims of all nationalities approach and treat them in a way analogous to the way saints are treated. The 'healthy' asked the sick to pray for them or for those close to them; the sick were given small gifts and pious objects, and were spontaneously stroked and caressed by strangers . . . and they were massed together at the front of rituals and were generally accorded a favoured treatment in all areas of the town." (Andrea Dahlberg, "The Body as a Principle of Holism," in Eade and Sallnow, Contesting the Sacred, 46)

${ }^{25}$ Conyers listserve message, posted February 8, 1995.

${ }^{26}$ Memorandum of Archbishop Lyke to Archdiocesan priests, January 17, 1992, quoted in Ann Marie Hancock, Wake Up America! Take My Heart, Take My Hand (Norfolk, VA: Hampton Roads, 1993), 195-96. Lyke's successor, Archbishop John Donoghue, has reaffirmed this position. For a well-developed statement of Catholic doctrine on visions, see Karl Rahner, Visions and Prophecies (New York: Herder and Herder, 1963).

${ }^{27}$ Eade and Sallnow, Contesting the Sacred, 5.

${ }^{28}$ Hancock, Wake Up America! A Spanish version of the book also appeared in 1993.

${ }^{29}$ When I visited Conyers as an observer, I hoped to approach several people to conduct interviews, but I hesitated on the grounds that I would have felt invasive or inappropriate interrupting the Rosary or the recitation of the apparition message. If the press looked like disbelievers in search of a spectacle, they were at least welcome witnesses, like the Roman soldier. I, on the other hand, had no such legitimacy (and I was also traveling with 
Nova Religio

a friend and my family, including a fussy two-year-old). In some ways, then, my ethnographic experiment failed; I didn't get much of a scoop. On the other hand, I found myself astonished by the intensity and focus of this massive group. There was little evidence of mass hysteria.

${ }^{30}$ Karen McCarthy Brown, Mama Lola: A Vodou Priestess in Brooklyn (Berkeley: University of California Press, 1991). Scholars in the humanities, such as Moshe Idel, are turning increasingly to ethnography as a supplement to more traditional, text-centered methods. The hermeneutic turn within anthropology makes this partnership even more plausible. This paper argues for a limited use of ethnographic research for the study of Nancy Fowler's apparitions. My prototype for the selective use of ethnography comes from Idel's Kabbalah: New Perspectives (New Haven: Yale University Press, 1988), 25-26.

${ }^{31}$ See Catherine Albanese's distinction between "ordinary" and "extraordinary" religion in America: Religions and Religion (Belmont, CA: Wadsworth, 1992), 6.

32 “To Bear Witness," vol. 2, 47.

${ }^{33}$ Mary Douglas, Purity and Danger (London: Routledge, 1976), 68-69.

${ }^{34}$ The variety of belief positions may be classified as follows:

(1) Complete Acceptance

(2) Affirmation

(3) Testing to Confirm

(4) Testing with Expectations of Confirmation

(5) Genuine Agnosticism: Testing May or May Not Confirm

(6) Testing with the Expectation of Denial

(7) Testing to Deny

(8) Limited Interest in the Event as Spectacle

(9) Indifference

(10) Total Dismissal

${ }^{35}$ Jean-Paul Sartre, "Existentialism and Humanism," in A Casebook on Existentialism, ed. William V. Spanos (New York: Thomas Y. Crowell, 1966), 280-81.

${ }^{36}$ Susan Sontag, On Photography (New York: Anchor, 1990), 4.

${ }^{37}$ My colleague, Darleen Pryds, also suggests that the photos could provide instant souvenirs for Conyers visitors.

${ }^{38}$ Jean Baudrillard, America, trans. Chris Turner (London: Verso, 1988), 37.

${ }^{39}$ Conyers listserve, message posted November 19, 1995.

${ }^{40}$ Conyers listserve, message posted November 20, 1995.

${ }^{41}$ Conyers listserve, message posted November 17, 1995.

${ }^{42}$ Balaban, "The Marian Apparition Site in Conyers, Georgia," 224.

${ }^{43}$ See Stephen D. O'Leary, "Cyberspace as Sacred Space: Communicating Religion on Computer Networks," Journal of the American Academy of Religion 59 (1996): 781-808. Perhaps not incidentally, the official Website of the Roman Catholic Church, Catholic On-line, begins with the following caption: "Catholic Online . . . Dedicating our on-line presence to Our Lady of Guadalupe," available on the World Wide Web at: http:/ / www.catholic.org/ index2.html.

${ }^{44}$ Ron Tesoriero, Why Do You Test Me? (Gosford, Australia: Published by the Author, 1994).

${ }^{45}$ Ibid., 18.

${ }^{46}$ Ibid., 74. By reporting these findings, I make no judgment on their validity. The emphasis here is on what participants do and say about the Conyers apparitions.

${ }^{47}$ Hancock, 50.

${ }^{48}$ Report by Philip Callahan, in Hancock, 51-52. Compare the role of doctors at Lourdes and San Giovanni Rotondo (Eade and Sallnow, Contesting the Sacred, 20).

${ }^{49}$ Conyers listserve, message posted April 19, 1996. 
${ }^{50}$ Conyers listserve, message posted April 1, 1996.

${ }^{51}$ Conyers listserve, message posted November 13, 1995.

${ }^{52}$ This textual dimension of the Conyers apparitions relates directly to the idea of sacred text, which I call the scriptural function, in my book, Walter Benjamin and the Bible (New York: Continuum, 1996)

${ }^{53}$ This embrace of technology would seem to differ from nineteenth-century apparitions, which were part of "a revolt against modernity" and a battle of "faith against reason, superstition against science" (Blackbourn, Marpingen, 374).

${ }^{54}$ See Pelikan, Mary, 218-22, and Carroll, Cult of the Virgin Mary, 222. 